\title{
Literatura e inclusão - o papel dos escritores guineenses no empenho contra a invisibilidade
}

\author{
Moema Parente Augel \\ Universidade de Bielefeld, Alemanha
}

\begin{abstract}
RESUMO: ESTE ARTIGO TEM POR FINALIDADE AFIRMAR QUE É ATRAVÉS DA LITERATURA QUE A GUINÉ-BISSAU SE TEM FEITO MELHOR REPRESENTAR PARA ALÉM DE SEUS LIMITES TERRITORIAIS, SENDO SEUS ESCRITORES RESPONSÁVEIS PELA DIVULGAÇÃO DE UMA IMAGEM POSITIVA DO PAÍS E POR SUA INSERÇÃO NA VASTA COMUNIDADE DOS FALANTES E LEITORES DA LÍNGUA PORTUGUESA. PRETENDO AQUI DEMONSTRAR COMO A EXCLUSÃO SE TRANSFORMA EM INCLUSÃO A PARTIR DA DICÇÃO ENGAJADA DOS ESCRITORES CONTEMPORÂNEOS GUINEENSES.
\end{abstract}

ABSTRACT: THIS ARTICLE SHOWS THAT IT IS THROUGH ITS LITERATURE THAT GUINEABISSAU IS BEST REPRESENTED OUTSIDE ITS BOUNDARIES SINCE ITS WRITERS CONVEY A POSITIVE IMAGE OF THE COUNTRY AND ITS ROLE IN THE VAST PORTUGUESE-SPEAKING WORLD COMMUNITY. THE AIM IS TO DEMONSTRATE HOW CONTEMPORARY DISCOURSE AMONG GUINEAN WRITERS TURNS EXCLUSION INTO INCLUSION AND HOW, IN THIS WAY, THE INVISIBLE SPEECHLESS AND MARGINALIZED BECOME VISIBLE.

PALAVRAS-CHAVE: INCLUSÃO/EXCLUSÃO SOCIAL - CENTROS HEGEMÔNICOS/PERIFERIA SUBALTERNA - DESCOLONIZAÇÃO - O PODER DA TRADIÇÃO E DO SAGRADO - ESTRATÉGIAS DE DESCENTRAMENTO

KEY-WORDS: INCLUSION/EXCLUSION - HEGEMONIC CENTERS/MARGINALIZED PERIPHERIES - DECOLONIALIZATION - THE POWER OF TRADITION AND OF THE SACRED - STRATEGIES OF DECENTRALIZATION 
ste artigo tem por finalidade afirmar que é através da literatura que a GuinéBissau se tem feito melhor representar para além de seus limites territoriais, sendo seus escritores responsáveis pela divulgação de uma imagem positiva do país e sua inserção na vasta comunidade dos falantes e leitores da língua portuguesa. Ao mesmo tempo, protagonizam, de forma decidida, os atores sociais até agora esquecidos ou reprimidos: os subalternos e marginalizados, a larga faixa populacional rural e urbana que constitui a maioria dos habitantes do país, com sua imensa e variada riqueza cultural ${ }^{1}$.

Os escritores guineenses assumem, na ainda jovem história da Guiné-Bissau, um papel de vanguarda intelectual, concorrendo, pelo labor literário, ao lado da música popular, para tornar esse pequeno país, com menos de um milhão e meio de habitantes e $36.000 \mathrm{~km}^{2}$ de extensão - um território um pouco maior do que o Estado de Alagoas -, menos invisível, menos ignorado dentro dos espaços onde o português é a língua oficial ${ }^{2}$.

No âmbito do núcleo temático deste número de Via Atlântica, levando em conta as bipolaridades centro/periferia, exclusão/inclusão e seus corolários dominadores/dominados, privilegiados/desprivilegiados, pretendo apresentar exemplos da representação literária, analisando como os escritores ultrapassam ou desconstroem mecanismos sociais, econômicos e políticos de exclusão.

Inclusão e exclusão representam temas clássicos da sociologia, tanto da sociologia estruturalista quanto da "teoria crítica", proveniente da "Escola de Frankfurt". Assim como esses conceitos têm servido para a análise de situações de indivíduos isolados (vítimas da pobreza, desempregados, homossexuais, prostitutas, drogados, criminosos) ou grupos sociais (camponeses, bairros marginais, por exemplo, onde predomina a precariedade das condições de vida, de infra-estruturas deficientes ou inexistentes), são igualmente utilizados para analisar o fato de estados ou grupos de estados (por exemplo, o assim chamado "Terceiro Mundo") serem excluídos ou desfavorecidos pelo

1 Para um estudo aprofundado sobre a literatura guineense, cf. AUGEL, 1998 e AUGEL, 2005.

2 A independência da Guiné-Bissau data apenas de 1973 (reconhecida por Portugal em 1974), e seus atuais contornos geopolíticos são fruto da prepotência imperialista. O país, constituído a partir de um artifício colonial, a famosa e desastrosa repartição da África pelos europeus no Congresso de Berlim (1884/85), fez parte de um complexo, antiquíssimo e poderoso emaranhado de povos e reinos que se combateram e se uniram ao longo de muitos séculos antes da chegada dos portugueses àquela região. 
desenvolvimento do capitalismo. Cientistas políticos e sociais, historiadores, analistas literários, entre outros, se têm ocupado largamente com tais fenômenos tão típicos da assimetria que domina o mundo contemporâneo, centrado no mercado e no lucro, na sede do progresso e do poder, responsáveis pela precarização das condições de trabalho e qualidade de vida de uma imensa parcela das populações dos países que gravitam na órbita do capitalismo.

A literatura que se está fazendo na Guiné-Bissau de hoje é reflexo da crise política, social e identitária que já se prenunciava e cuja explosão as obras surgidas na década de 1990 profetizavam e confirmavam. Seus poetas e prosadores reafirmam, a cada passo, a crença nas culturas nativas, lutam contra a anulação cultural do acervo simbólico das etnias, solidarizam-se com os excluídos, insistem na necessidade da conjugação de esforços para retirar o país da ruína social e política em que se encontra no momento. E, pelo viés da estética e da representação simbólica, através do discurso literário, os autores guineenses apontam para possíveis saídas, desconstruindo a história hegemônica, deixando falar e agir outros protagonistas. Ao mesmo tempo, a voz desses escritores leva, a ouvidos atentos de outros espaços onde o português é falado e é lido, a presença do país de Amílcar Cabral, quebrando um silêncio secular, desvelando as riquezas culturais do mosaico étnico guineense.

Pretendo aqui demonstrar como a exclusão se transforma em inclusão a partir da dicção engajada dos escritores contemporâneos guineenses. Para melhor situar minha argumentação, depois de um breve panorama dos principais momentos da literatura guineense desde a independência aos nossos dias, passarei a apresentar, através de exemplos, a dupla contribuição da literatura que se está fazendo na Guiné-Bissau: de um lado, como os autores se esforçam para tornar visíveis ao mundo exógeno as manifestações culturais desse país, em sua riqueza e multiplicidade, e do outro lado, como o tecido textual deixa transparecer a articulação dos esforços da população para ultrapassar as mazelas do passado colonial e se integrar no contexto da modernidade. Pretendo, ainda, chamar a atenção para o empenho dos autores em deslocar o olhar do centro hegemônico, autocelebrado, para a periferia subalterna, silenciada mas não silenciosa. 


\section{Breve mapeamento da literatura na Guiné-Bissau}

Não levando em conta nem os romances e poemas da assim chamada literatura colonial ${ }^{3}$ nem tampouco as recolhas e transliterações da rica oratura regional ${ }^{4}$, pode-se afirmar que somente depois da independência tiveram lugar as primeiras publicações literárias assinadas por autores guineenses.

Um pequeno volume de versos, datado de 1963, de autoria de Carlos Semedo, marca os inícios da literatura guineense. Na década de 1970, registra-se apenas a publicação de modestas coletâneas de poemas, entre elas Mantenhas para quem luta! (1977) e Momentos primeiros de construção - Antologia dos jovens poetas (1978). Conduto de Pina publicou em Lisboa, numa edição do Autor, uma simples plaqueta que passou quase desapercebida, tendo sido de fato a primeira publicação individual depois da independência no campo da poesia: Garandessa di no tchon ("Grandeza da nossa terra", 1978). Na década de 1980, apareceram dois livros individuais de poemas: A luta é a minha primavera, de Vasco Cabral (1981) $)^{5}$ e Não posso adiar a palavra, de Hélder Proença (1982). Depois de uma larga pausa, é lançada a Antologia poética da Guiné-Bissau (1990), a mais completa de todas as obras conjuntas do país. São catorze autores, quase todos tendo figurado nas coleções precedentes de 1977 e 1978. O extenso prefácio de Manuel Ferreira, com o título Em louvor da esperança, é um comentário minucioso a respeito dos autores e poemas daquele volume. Dois anos mais tarde, aparece $O$ eco do pranto - A criança na moderna poesia guineense (1992), uma coletânea com trinta e três poemas, só com a temática da criança, escritos por nove autores.

3 Denomina-se em geral literatura colonial os textos escritos por metropolitanos que, tendo passado algum tempo na África ou em outros espaços colonizados, produziram textos em que o olhar etnográfico ressaltava a alteridade e em que a descrição dos costumes e do ambiente em que vivia o africano podia até mesmo representar um interesse verdadeiro pelo país e pela gente, ultrapassando o mero pincelar da cor local. Sempre, porém, constituindo um olhar de fora, onde se mesclavam o fascínio e o repúdio, camuflado às vezes em piedade ou paternalismo. Muitos desses textos fazem parte do cânone literário e são sempre citados e utilizados em manuais escolares e em antologias. Sem entrar no mérito nem nas qualidades literárias das obras desse cariz, não vejo como incluí-las no acervo literário guineense.

4 A respeito da oratura, cf. principalmente os trabalhos de Teresa Montenegro, constantes das referências bibliográficas. Cf. ainda AUGEL, 1998, p. 42-51.

5 Vasco Cabral, que nasceu em 1926, morreu em Bissau quase octogenário, em 2005, festejado como o primeiro dos poetas guineenses depois da independência do país. Mas, na verdade, esse galardão cabe a Conduto de Pina. 
Essas primeiras coletâneas trazem versos plenos de emoção e otimismo, em que os autores se empenham em exaltar a revolução vitoriosa e homenagear os heróis nacionais. Cantam o chão reconquistado, a Guiné libertada, a recém-criada Guiné-Bissau. É esse o momento inaugural da formação da nacionalidade. O tempo pós-revolucionário, com todas as suas implicações positivas, é tematizado de forma recorrente, numa apologia aos "momentos primeiros da construção".

Somente a partir da década de 1990 é que se pode falar de um desabrochar da literatura guineense, datando dessa década uma série de publicações individuais de poesia e as primeiras obras em prosa. Depois da fase ufanista, já quase no anunciar do novo milênio, quando os excessos da má governança atingem o paroxismo, são expressas simbolicamente as engrenagens das estratégias neocoloniais que mantêm instalado na cabeça dos indivíduos o sentido de inferioridade e de exclusão, de resignada anuência ou passivo desencanto, roubando-lhes a identidade e a autoconfiança. A descolonização se apresentou como uma quimera e os escritores expressam, em prosa e em verso, os efeitos do neocolonialismo e seu corolário, a autocolonização, fenômeno que corrompeu os dirigentes e fez gorar a utopia.

Dentre os livros de poemas, destacam-se as obras enfeixadas na Colecção Kebur: em 1996, foram lançados Noites de insónia na terra adormecida, de Tony Tcheka; Arqueólogo da calçada, de Félix Siga, e Entre o ser e o amar, de Odete Semedo, a primeira mulher a publicar um livro de poemas individual ${ }^{6}$. Registre-se ainda, inaugurando aquela coleção, a antologia de poemas em crioulo, a língua veicular das camadas urbanas na Guiné-Bissau: Kebur-Barkafon de poesia na kriol, também de 1996. Em 1997, a Colecção Kebur publicou três obras póstumas: Djarama, com os poemas de Pascoal D’Artagnan Aurigemma (1938-1991), Os marinheiros da solidão, de Jorge Cabral (1952-1994), além da obra do compositor e poeta José Carlos Schwarz (1949-1977), Ora di kanta tchiga ${ }^{7}$.

6 Domingas Samy foi a primeira mulher guineense a publicar uma obra literária, tendo sido autora do primeiro livro em prosa, uma pequena coletânea de três contos intitulada A escola (1993).

7 José Carlos Schwarz, com o conjunto musical Cobiana Djazz, compondo e cantando só em crioulo, tematizando a realidade cotidiana nessa língua proibida, acabou perseguido e preso pelas autoridades coloniais. Com suas canções, desempenhou um importantíssimo papel nesse período delicado da descolonização e continua a ser considerado o intérprete das aspirações do povo, permanecendo um ídolo popular. Antes de serem publicados livros na Guiné-Bissau, foram gravados dois álbuns de canções do conjunto Cobiana Djazz e um disco individual de José Carlos Schwarz. 
O romance guineense foi inaugurado por Abdulai Sila, que lançou sucessivamente Eterna paixão (1994), A última tragédia (1995) e Mistida (1997), todos publicados em Bissau pela primeira (e ainda única) editora particular do país, a Ku Si Mon Editora. Abdulai Sila é sem dúvida o mais importante prosador guineense. Seus três romances têm em comum a revisão crítica da história de seu país.

Filinto de Barros, em Kikia matcho (1997), procede a uma interpretação do processo de formação social e política da Guiné-Bissau, estabelecendo uma ligação entre o factual, a memória e a ficção. Tem-se ali um registro distanciado do discurso oficial, e a ótica da abordagem é claramente a partir da visão dos vencidos, dos subalternos.

O novo milênio traz a promessa de uma nova safra de bons autores. A par de publicações na língua guineense, como o livro de poemas de Nelson Medina (Sol na mansi, "o sol se levantará, surgirá", 2002), destaca-se sobretudo Odete Semedo, primeiro com dois volumes de contos: Sonéa - Histórias e passadas que ouvi contar I e Djênia - Histórias e passadas que ouvi contar II (Bissau, 2000), nos quais a tradição oral constitui um importante componente. Da mesma autora, sobressai a obra excepcional, canto épico-lírico em versos, intitulada No fundo do canto (publicada em 2003, em Viana do Castelo), espelhando a experiência traumatizante da catástrofe da guerra de 1998-1999 e as conseqüências políticas, econômicas e sociais dali resultantes.

Através da leitura desses autores, acompanhamos a oposição anticolonialista, marchando passo a passo com a infiltração neocolonial; uma das manifestações dessa reação é o desmantelamento do discurso dominante, a desconstrução da narração hegemônica da nação através de vários recursos como a ironia, o sarcasmo, o humor, o burlesco, mas também com o bisturi da denúncia, da raiva e da mágoa. A apropriação antropofágica do instrumento de comunicação por excelência que é a língua, processando uma transgressão das normas estabelecidas do "bem escrever", de forma consciente e politicamente direcionada, africanizando, crioulizando o idioma do colonizador, tem sido outro recurso, outro brado de independência e de auto-afirmação. Escritores como José Carlos Schwarz, Pascoal D’Artagnan Aurigemma, Tony Tcheka, Félix Sigá, assim como Odete Semedo, Abdulai Sila, Filinto de Barros, assumiram seu papel social, emprestando voz aos que até então eram silenciados, identificando-se com eles, dando-lhes visibilidade, denunciando a exclusão social. 


\section{Estratégias de inclusão}

A linguagem literária é capaz tanto de legitimar o que o discurso sociopolítico aponta, quanto de questionar, desconstruir o que a dicção autoritária e hegemônica preconiza. A auto-reflexão que se conheceu na Guiné-Bissau, na cena pública, até os anos 1990 foi quase apenas a dicção hegemônica, sob a forma de discursos oficiais. Os ideais de nacionalidade e de cidadania eram transmitidos ao povo pelos meios de comunicação disponíveis. A imprensa e sobretudo o rádio, indispensável num país de tantos iletrados, foram instrumentos de propaganda e de doutrinação, primeiro do partido clandestino, depois do partido vencedor e único, o PAIGC. Através de tais porta-vozes, se foi plasmando a história "oficial" da nação guineense. As classes dominantes, apropriando-se do prestígio devido à participação nas lutas de libertação, disso se têm servido para legitimar seus atos e conservar-se no poder.

Os versos que utilizei como epígrafe para este artigo anunciam a postura desses escritores-griots - bardos e profetas - djidius de caneta e papel, irreverentes e atentos, "sem papas na língua", incomodamente conscientes de seu lugar e do alcance de suas palavras. Ao elevarem suas vozes polífonas e dissonantes, abrem espaço para uma tomada de consciência que funciona ao mesmo tempo como denúncia e como auto-afirmação: "Eu sou o poeta proibido / de grito aglutinado", exclamou Pascoal D'Artagnan Aurigemma (AURIGEMMA, 1996: 121).

De uma forma alargada, a exclusão social pode ser vista como um processo sócio-histórico marcado pela discriminação e o afastamento das instâncias da vida social de pessoas ou grupos de pessoas, impedidos de participar dos mercados materiais, culturais ou simbólicos. Presente nas várias formas de relações econômicas, sociais, culturais e políticas das sociedades, a exclusão é um fenômeno flagrante das periferias urbanas e das áreas rurais, em que segmentos da população são marcados por uma vivência de privação, abandono e degradação, impedidos do direito de poder partilhar bens públicos. Dentro desse âmbito, estão a pobreza, a desigualdade, a não-representação pública e, conseqüentemente, a subalternidade, a discriminação, a inferiorização e a perda da auto-estima.

Em "Retrato de um natal", Pascoal D'Artagnan Aurigemma traça um desses quadros patéticos do cotidiano dos centros urbanos: "Juntos - mesmo 
chegadinhos / mamãe filho \& miséria / no calendário social da vida / / Não há gestos de amor / nem fôlego d'alguém / a minorar-lhes a dor" (AURIGEMMA, 1996: 75).

Nomear os problemas e as questões que mais afligem o povo é para Pascoal D’Artagnan Aurigemma uma forma de responsabilidade social. A empatia do poeta leva-o a chamar a si mesmo de "cantor miserável", ao evocar os estivadores, os trabalhadores braçais e sofredores, "uma data de anónimos", individualizados, entretanto, pelo poeta que lhes desfia sonoramente os nomes no belo poema "O cantor miserável da noite no cais":

Eu sou o cantor miserável da noite no cais! // Estão ali / no cais / Ansumane Becô, Infamará, Bicinti Cabupar, Malan Seidi, Djodje Badiu, Batipom Cá ... / Estão ali uma data de anónimos / da noite no cais! [...] // Gente para carrego de sacos fartos e tantas caixas de / whisky and coca-cola and beer / que o mundo galã há-de consumir / em noites diferentes / das noites no cais... (AURIGEMMA, 1996: 55).

A exclusão social, como um processo sócio-histórico, sempre existiu, em maior ou menor proporção, com dramáticas conseqüências. Os desprivilegiados são tragados pela engrenagem desmoralizante da marginalização que lhes barra o acesso aos subsistemas da sociedade (a educação, a saúde, o exercício da própria cultura), quase sempre sem oportunidades de escapar do círculo vicioso da privação, rejeitados dos mercados materiais ou simbólicos, impedidos de romper o esquema montado a partir das oposições binárias, assimétricas, da lógica patriarcal e imperial que ainda predomina em nossas sociedades pós-coloniais.

Tony Tcheka, outro poeta na mesma linha de engajamento e participação, tem um poema muito expressivo em que, no triângulo constituído pelo enunciador, pelo receptor e pelo objeto em foco, numa indignação inconformada, aponta os motivos do opróbrio e da vergonha que assim tomam corpo, não podendo ser ignorados: "A dor encosta-se a mim / abraça-me forte / espalha-se pelo corpo / em glândulas de fome [...] / Estou no meu tempo / no meu espaço / na minha tabanca / onde festa / é choro / é doença / é criança morrendo / dia a dia / hora a hora!" (TCHEKA, 1996: 69).

O escritor, imbuído de seu papel social, torna-se representante das camadas populares, identificando-se com elas, trazendo-as para o centro dos aconteci- 
mentos. A vOz poética assume na primeira pessoa as aflições e as agruras da dura realidade cotidiana, a decepção pelas utopias fracassadas que aviltam a terra natal: "Guiné sou eu [...] Guiné somos todos / mesmo depois da esperança" (TCHEKA, 1996: 80). "Guiné” é Bissau tentando emparelhar-se com as grandes metrópoles, é o país enfrentando o desafio do desenvolvimento, mas também é muito mais. A história hegemônica oficial festeja os heróis nacionais e as façanhas da vitória contra o colonizador, mas o poeta - atento, solidário - não esquece a vasta maioria silenciosa e marginalizada: "Guiné / és tu / camponês de Bedanda teimosamente / procurando a bianda na bolanha [...] / / Guiné / és tu / mulherbideira / em filas de insónia / noites de kumpra pon" (TCHEKA, 1996).

Tony Tcheka vai longe na sua crítica, apontando "o desespero a fome / a doença os bolsos minguados / todos estes fiéis companheiros" ("Desafio", ibid., p. 61) que lamentavelmente caracterizam o dia-a-dia do país. Denuncia a "barriga da criança minguada" que "inchou / inchou / parece um balão / flutuando no corpo menino" ("Melodia do desespero", ibid., p. 73). A carência e o sofrimento gerados, indevida e injustificavelmente pela falta de pão ou de arroz, ocupam o escritor-jornalista que tematiza a questão em muitos versos: "na mesa / falho de tudo [...] / a velha plaina / o martelo / o cutelo / o malho / não fazem pão [...] / o tacho faminto / sobre-a-mesa / plaina lentamente a fome" ("Falsa valsa", ibid., p. 56).

A imagem familiar das mulheres africanas transportando sobre a cabeça grandes cargas assoma aos olhos dos leitores, transfigurada pela dimensão poética: Mame / sukundi / si dur / bas / di kabas / finkandadu / na urdidja / di kansera. Pode-se ouvir, na cadência dos versos em crioulo, os passos difíceis da Mame, que "esconde sua dor sob o cesto, firmemente equilibrado na rodilha" que traz sobre a cabeça e que abriga também toda a sua vida infeliz (a kansera, na língua guineense). Lá segue ela, penosamente, na / kalkañar / iandadur / - tuku di pe. Sua vida, Mame a ganha com os próprios pés ("o calcanhar andarilho”), metonímia para representar que ela não depende de ninguém, tem sua independência, vive com seu próprio esforço. A mulher em pé, sobre seus calcanhares, que não se curva nem se abate diante das agruras da vida. Mais do que o exercício da faina diária de amassar o grão para o alimento, Mame amassa a própria fome la ki ta / masa / fomi, vence-a, suportando o fardo da "sua vida sacrificada, apoquentada", pa i ka / pukental / si bida / pukentadu ("Dur di Mame", ibid., p. 20). 
Realçando a presença de atores sociais geralmente relegados ao esquecimento ou ao desprezo, os escritores guineenses, engajados na revisão do estado de desbarato reinante no país, navegam contra a corrente e contra a tendência geral de inferiorização - e mesmo estigmatização - daqueles segmentos e, com textos destituídos de preconceitos, tecem uma inesperada rede de respeito e de simpatia.

Félix Sigá, como outros escritores guineenses aqui apresentados, recupera com sua poesia a presença dos marginalizados, identificando-se com eles. A postura do autor, primando em ser visto como o Outro, em ser mesmo esse Outro - o subalterno, ignorado pela sociedade -, confere obrigatoriamente visibilidade, voz e representação a esses excluídos. O autor evoca, por exemplo, os trabalhadores, os operários da construção civil, em Bissau como em muitas outras partes do mundo, espoliados, vítimas inocentes, despersonalizadas e reduzidas à mera condição de insetos. Sobre a estrada seminua / há formigas apressadas / formigas humanas. Sem compensação de ordem material, a tarefa que têm a cumprir é grandiosa: esses obreiros anónimos como formigas / constroem uma pátria [...] / antecipando o amanhã.

A linguagem dessa exploração do homem pelo homem é a mesma em toda parte do mundo: E na língua das canseiras / a verdade que traz. / o suor das lições / é culta e universal. Mas o poeta esperou em vão que seu país, depois da vitoriosa expulsão dos colonizadores e sobretudo depois da bem-sucedida mudança política, alcançasse uma outra realidade: 0 sol de transição (SIGÁ, 1996: 67-68).

Félix Sigá vai buscar sua inspiração na população plurifacetada da cidade de Bissau e esboça, com traços seguros, pinceladas do cotidiano. Seu olhar atento ora cai sobre uma velha mulher carregada com um pesado fardo, ora sobre velhas e crianças / todas mulheres - todas bideiras, como a vendedora de comida que já não quer seguir os antigos costumes que obrigavam a mulher ao recato e à discrição; ora, ainda, sobre a empregada doméstica ou a prostituta, de nome Mary, de lábios pinta-pintados. Mas também os rapazes bem-vestidos e atentos à moda, o boêmio sempre bêbado e sonhador, os militares que dançam fardados a sua civilidade, o mendigo arqueólogo da calçada e mesmo os emigrantes desalojados, emigrados da África-mãe são alvos da sua observação plena de realismo, da sua ironia e seu sarcasmo, da sua simpatia participativa.

O jornalista do cotidiano aflora no poema "Reportagem" (ibid., p. 101-104), quando, em tom narrativo e prosaico, evoca com minúcias uma cena vivida durante uma curta viagem aos arredores da capital, onde novamente as persona- 
gens principais são mulheres do povo, doceiras a fritar panquete quente-quente numa parada da estrada de Prábis. O autor é muito bem-sucedido na pintura da cena, delineando um verdadeiro quadro de costumes típicos regionais, ao sabor popular. Pode-se acompanhar os movimentos da matrona vestida com pano tingido $e$ sutiã branco (ibid., p. 101), ou admirar uma noiva com o primeiro bambaram já / cabelo tecido pequenino-pequenino / brincos que dançam / com os vira-virar cabeça dela / lábios pretos e gengivas aruis (ibid., p. 102), vendo-se mais adiante seu homem / com uma linda caneta sem carga, muito entretido fazendo que lia e tendo na mão um texto em russo: folheava o $A B C$ da Politica soviético / e mascava um pauzinho de badós-dós, pois estudou comunismo lá no socialismo tcheco... (ibid., p. 103).

\section{A voz dos antepassados}

A exclusão apresenta-se ainda em um outro contexto: a exclusão cultural.

O dominador, para submeter o colonizado, considerou necessário tirar-lhe a língua, as crenças, as tradições, roubar-lhe a capacidade de escolha própria, quebrar-lhe a vontade. Desprestigiar, desconsiderar os saberes e as culturas locais em detrimento da cultura imposta, embriagando o colonizado com o elixir da civilização, foi uma estratégia recorrente da maior eficiência. O "extermínio constante dos traços originais" (SANTIAGO, 1978: 16) e autóctones caminhou lado a lado com o empenho em impor a presença e a cultura européias como centro irrefutável de referência. Tentou-se, por todos os meios, abafar as tradições, vistas como antiquadas e primitivas. Os regimes autoritários, como em um verdadeiro pacto do esquecimento, fizeram valer sua visão da história, impuseram uma única memória oficial, a memória e a história dos vencedores. No caso específico da Guiné-Bissau, seus escritores, por muitos e diversos caminhos, empenham-se em dar voz ao avesso da história, trazendo à tona o passado emudecido e conspurcado.

Odete Semedo, no "Consílio dos Irans", a terceira parte de seu livro No fundo do canto (2003b), promove o reconhecimento e a valorização dos princípios religiosos, culturais e identitários do povo guineense.

8 O iran é a divindade, o espírito sagrado que pode proteger ou castigar, sendo um "objeto de culto e de consulta das populações animistas da Guiné” (MONTENEGRO e MORAIS, 1995: 222). 
Os ritos são elementos básicos, essenciais, da sociedade tradicional africana. Para tudo há cerimônias rituais, o sagrado e o invisível acompanham todos os passos da vida cotidiana. Os ancestrais, os feiticeiros, os curandeiros, os espíritos e os deuses influenciam os negócios e os acontecimentos; os adivinhadores da sorte livram os indivíduos das forças maléficas, os castigos divinos e os sinais de proteção são onipresentes. A vida mítica faz parte da visão de mundo dos africanos, para os quais o sobrenatural desempenha um papel da maior importância. Trata-se da "ontologia do invisível" de que fala Anthony Appiah (1997, p. 162).

Segundo Appiah, o "apelo ritualístico público a espíritos invisíveis, em ocasiões cerimoniais, faz parte de uma forma de vida em que tais apelos costumam ser feitos em particular" (APPIAH, 1997: 162). O "Consílio dos Irans" reúne todas as entidades protetoras com o intuito de salvar Bissau e o país da catástrofe iminente, livrá-los do flagelo que os abate, castigar os causadores da desgraça, pois "há culpados... / que não fiquem mudos / nem impunes" (SEMEDO, 2003b: 83).

Os mitos e as crenças do passado persistem no cotidiano das gentes, na continuidade ontológica do ser guineense, na sua função espiritual e social, sendo retransmitidos pela rede da oralidade e, principalmente, pela prática familiar e pela celebração comunitária. Em No fundo do canto, o específico do povo guineense é posto em foco através da multiplicidade e da exclusividade de suas linhagens e da sua ancestralidade. Os irans e seus totens são convidados pela voz poética para um ato de resgate, de salvação. $\mathrm{Na}$ multiplicidade e na exclusividade de suas linhagens e da sua ancestralidade, o pacto clânico é reafirmado. O episódio da grande reunião (a kontrada) é uma preciosa lição sobre as complexas e vivas tradições locais. "Tanta súplica e chamamento... / tamanha invocação / [...] irans e defuntos se reuniram / [...] / é hora de ouvir a nossa djorson / e os nossos defuntos" (SEMEDO, 2003b).

Odete Semedo evoca pelo nome todas as etnias de que se compõe o povo guineense. Exatamente no momento em que a nacionalidade está posta em perigo pelo drama da guerra, a autora torna visíveis os pilares ancestrais em que se sustenta o ainda tão recente edifício nacional. "Nomear", "historiar" são verbos e são ações com os quais a autora narra - e celebra - a identidade coletiva, sufocada, excluída pelo colonialismo e pelo neo e autocolonialismo. Nomear as etnias, seus irans protetores, seus totens e arquétipos é dar visibilidade, num território tão diferenciado, à trama da História, é cartografar as 
diferentes etapas dos movimentos migratórios, da constituição do território guineense, pois as diversas linhagens são ilustrações vivas dessa mobilidade, desse dinamismo demográfico e do entrelaçamento social e étnico de que é composta a Guiné-Bissau.

A matriz espacial (o território, a área geográfica em que o país se desdobra) e a matriz temporal (as tradições, o passado histórico) são duas vertentes utilizadas por Odete Semedo para inserir a Guiné-Bissau no contexto africano, quando forças exógenas a ameaçavam. No ambiente místico e mítico em que decorre o "Consílio dos Irans", a tradição ancestral vem à tona, fortalecendo a confirmação de uma unidade com base na evidente diversidade e conseqüente disparidade, vistas como algo positivo, pois "da barriga duma parida / saem filhos / corre em cada um o mesmo sangue [...]. São como os cinco dedos de uma mão / os defuntos as almas e os irans / protectores das djorson da Guiné" (SEMEDO, 2003b: 97).

A literatura é que melhor registra as idiossincrasias culturais, afirma Julio Ortega, "'onde se vê como a mentalidade enlaça o individual com o coletivo, como os procedimentos empíricos se imbricam com as inclinações imaginárias, como a subjetividade se relaciona com a realidade externa" (ORTEGA, 1988: 9).

\section{Resgatando a dignidade perdida}

Prosseguindo no meu mapeamento das estratégias de inclusão e de desconstrução levadas a efeito pelos escritores guineenses, darei dois exemplos, bastante diversos um do outro, de uma revisão de aspectos da história hegemônica.

A historiografia eurocentrada silenciou a história africana, apropriando-se da cronologia, iniciando a contagem da história na África com a chegada dos navegadores europeus. As terras foram "descobertas" e a partir de então passaram a existir nos mapas e na percepção dos ocidentais.

Durante o regime colonial, a administração e seus regulamentos estavam quase sempre divorciados da vida social de base local. Muitas vezes, porém, por oportunismo ou conveniência, o sistema político colonial estabelecia uma aliança entre a representação do poder colonial local e os poderes tradicionais; essa aliança foi, durante o período das lutas libertárias, um dos pilares 
da dominação estrangeira, procurando enfraquecer o adversário, acenando com certas vantagens e dividindo os africanos. Os régulos "evoluídos", que recusavam a colaboração e a aliança com o colonizador, eram considerados "como o núcleo da subversão donde saem os chefes e os pioneiros da rebelião” (FERNANDES, 1993: 43).

Contrariando a versão estereotipada do colono passivo e submisso, o grande régulo de Quinhamel, pequena localidade próxima a Bissau, um dos protagonistas do romance $A$ última tragédia, de Abdulai Sila (1995), é a personificação da resistência dos dominados contra o jugo opressor. Sila traça o perfil do africano mentalmente emancipado, seguro de si, que recusa a humilhação e a subserviência. Consciente de sua responsabilidade como chefe da comunidade nativa, dirige com sabedoria sua gente e reconhece que muitos males provocados pelo colonizador poderiam ser evitados se o povo tomasse consciência da própria força e capacidade: "No fundo, este é que era o problema do preto: tem medo de fazer mal ao branco, enquanto que o branco faz mal ao preto todos os dias que o sol nasce" (SILA, 1995: 64).

O régulo Bsun Nanki é a antítese da imagem do colonizado dependente e incapaz, opondo-se ao discurso que asfixia o africano dentro dos limites rígidos do estereótipo, reflexo da arrogância do dominador que tantas vezes promoveu o silenciamento das culturas nativas pelas mais diversas estratégias: "Ninguém diz isto está bom, aquilo está mal e depois procura pensar por quê. Tudo o que o branco faz é porque está bom. O branco é que estava a pensar no lugar do preto. Mas branco é homem como qualquer outro homem!" (SILA, 1995).

A autocrítica, em busca das causas do desbarato em que se encontra a sociedade guineense, não vem da classe política ou administrativa.

Filinto de Barros inscreve a ação do romance Kikia matcho (1997) num contexto das camadas populares do submundo dos bairros pobres e decadentes de Bissau, onde se faziam sentir concretamente os indeslindáveis impasses provocados pelas infra-estruturas deficientes e pela incompetência da administração. Fixa os acontecimentos na etapa histórica pós-revolucionária, a partir da tensão existente entre os "comandantes", de um lado, e, do outro, os antigos e legendários "combatentes para a liberdade da Pátria", representantes do mundo dos "companheiros da desgraça", destacando a presença e a participação dessa faixa populacional na construção e nos destinos da nacionalidade: 
"Como explicar que dum grande combatente tenha surgido um miserável? [...] Uma coisa era certa, 'N Dingui lutou, comandou, detém medalhas de Combatente da Liberdade da Pátria, e está ali seco que nem um carapau. Mas seco em tudo, até na audiência que lhe serve de velório!” (BARROS, 1997: 22).

Abandonando a perspectiva da camada dirigente, recusando a fala hegemônica, que também foi a sua, com conhecimento de causa, Filinto de Barros, veterano das lutas de libertação, companheiro de Amílcar Cabral, tendo ocupado vários cargos ministeriais ao longo dos vários governos de seu país, no único livro que escreveu, indica sem piedade a procedência dos problemas que estão na raiz da desgovernança e que tanto dificultaram a consolidação do Estado guineense: "Que interesse tinha, se o comboio da independência lhe havia escapado? Para quê questionar, se a magra pensão de Combatente não chegava para comprar um saco de arroz?" (BARROS, 1997: 20).

A imagem do guerrilheiro, heroificado pela sua bravura e seu sacrifício em prol do bem comum, é uma figura ícone que povoa a imaginação nacional e é um dos apelos constantes do discurso oficial hegemônico. O outro lado da medalha é o estado de abandono real em que os antigos guerrilheiros vivem, a precariedade das instalações dos quartéis, os baixíssimos salários, que nem ao menos são pagos regularmente - nada disso é ficção. O ex-combatente N Dingui, morto e transformado em kassissa, isto é, em ser que não é deste mundo, errante e sem paz, foi escolhido para levar os vivos a se corrigirem e a mudarem tudo o que aconteceu contrário aos ideais revolucionários. É preciso verificar o que se fez de errado. É preciso "enxergar mais longe e descobrir os beneficiários últimos das acções criminosas" (BARROS, 1997: 138), buscar os verdadeiros autores, pois não havia dúvida de que aquela revolução se tinha autodestruído e que "teimava em afastar-se do caminho traçado" (ibid., p. 140). É preciso que os comandantes escutem certas verdades (ibid., p. 142).

\section{Balanço de uma fortuna crítica}

Passando em revista a fortuna crítica da literatura guineense, ocorre-me a pergunta: dentro do contexto africano e dentro do espaço das literaturas escritas em português, que "fortuna", que sorte, que repercussão se espera para as letras e os autores da Guiné-Bissau?

Encarando um conjunto mais amplo, dentro do contexto da "literatura mundial", ou pelo menos ocidental, sabe-se que o interesse por Angola, Moçambique, Cabo Verde, São Tomé e Príncipe ou Guiné-Bissau por parte de 
outros países não-africanos, com exceção talvez de Portugal e mais recentemente do Brasil, continua bastante reduzido, incluindo a literatura. Isso pode ter várias razões. Fala-se, por exemplo, que apenas 2,5\% das publicações mundiais são editadas na África. Não sendo a língua portuguesa muito accessível aos leitores anglófonos ou francófonos, as dificuldades e os impedimentos somam-se e se perpetuam.

Motivadas primeiramente pelas lutas de libertação, surgiu um número razoável de coletâneas estrangeiras com poemas africanos contemporâneos - e as há em francês, inglês, holandês, espanhol, italiano, tcheco, russo, húngaro, como é possível constatar pelas referências sobretudo na grande obra bibliográfica de Gerald Moser e Manuel Ferreira. Em algumas aparece também uma tênue presença da Guiné-Bissau. Com poucas exceções, essa defasagem tem perdurado na atualidade, e os autores guineenses da década de 1990 quase ainda não foram descobertos.

É lastimável o silêncio que em geral paira em torno desse país, e a literatura representa, sem dúvida, o melhor canal para se abordar o ainda tão desconhecido mundo africano. No que diz respeito à Guiné-Bissau, é a literatura, como procurei demonstrar neste artigo, que vai resgatar o país da marginalização, conferindo-lhe alguma visibilidade diante dos demais membros da comunidade dos países de língua oficial portuguesa. É lamentável verificar que até em publicações recentes prolonga-se a mesma omissão da época de Manuel Ferreira, como se a Guiné-Bissau ainda fosse "um espaço em branco" em relação ao mundo das letras. Tal situação é devida, em grande parte, às precaríssimas condições de divulgação dentro do próprio país, que ainda não se ocupou concretamente em desenvolver uma política cultural que impeça a multiplicação dos silêncios e do desconhecimento que envolvem o país e suas culturas. Autores como Tony Tcheka, Félix Sigá, Pascoal D’Artagnan Aurigemma, Odete Semedo, Abdulai Sila, Filinto de Barros têm prestado seu contributo para superar tal situação deficitária, sem se desencorajar em face da falta de um público ledor mais amplo, da falta de livrarias, do baixo poder aquisitivo, da baixa escolaridade, da pouca circulação dos bens culturais.

Para o propósito das minhas reflexões sobre a literatura guineense, servime dos termos "inclusão" e "exclusão" como descritores de uma situação de não-conhecimento e não-reconhecimento tanto no plano microssocial, da 
realidade étnico-social da sua população, caracterizada por décadas de má governança, de elitismo, de menosprezo pelo povo no nível do discurso e no da ação político-econômico-social no seio do próprio país, quanto também no plano macrossocial, uma vez que a Guiné-Bissau e sua literatura são praticamente ignoradas no mundo acadêmico e político. O país é tão pobre e pouco interessante que de fato é quase inexistente nas agendas do mundo, e a política nacional é tão alienada da realidade do seu povo que a literatura parece uma das poucas vozes, se não a única, a gritar pela tomada de conhecimento da realidade daquele território que se quer nação.

No nível da macropolítica, continua a dominar a antiga lógica imperial a que já se referia Frantz Fanon, em que a exclusão se efetiva não apenas na separação física e geográfica (o espaço colonial sendo fronteirizado e departamentado), como também no plano dos direitos, dos privilégios e, inclusive, no plano das representações e dos valores (FANON, 1961: 31). O sujeito colonizado é concebido no imaginário metropolitano como o "Outro", e, como tal, é alijado tanto quanto possível dos princípios que definem os valores da civilização.

Os países periféricos, pós-colonizados, apartados dos benefícios da ordem econômica mundial, continuam a gravitar em torno dos países centrais, numa nova dependência neocolonial. Michael Hardt, em seu livro Império, escrito em parceria com Antonio Negri (2003), vai mais longe que Fanon: a nova ordem mundial que está surgindo e submetendo o mundo a uma globalização com efeitos positivos e negativos está criando um novo poder (a "soberania imperial"), em que a ideologia do mercado mundial se liberta do contexto nacional, abrindo espaço à heterogeneidade, abarcando todas as culturas, religiões e origens étnicas. Todos são bem-vindos ao "Império" - desde que aceitem o lugar que lhes é indicado. As empresas "imperiais" fazem da multicultura e da multietnicidade a chave do sucesso, patenteando a capacidade de apropriação e reapropriação do sistema capitalista.

A Guiné-Bissau continua sendo um espaço marginal em relação tanto à África quanto à Europa e aos países industrializados, com consideráveis deficiências estruturais em questões de educação, de saúde, de transporte, primando pela ausência de indústrias, com graves lacunas na prática da democracia e na responsabilidade política, administrativa e jurídica. Sem matéria-prima a ser explorada, sem mercado a ser conquistado, sem infra-estruturas que possam seduzir investimentos estrangeiros, o país, como afinal a África negra 
quase na totalidade, está do lado dos perdedores da globalização, dos excluídos da dinâmica do capital.

País de escassa, de quase nenhuma tradição literária escrita, país de poucos e irregulares jornais ou semanários, onde o rádio e a televisão estão dominados pela interferência estrangeira (a brasileira, com as telenovelas ou as pregações evangélicas; a portuguesa, com o futebol e as notícias da "metrópole"), nesse espaço modesto e distante dos centros de decisão mundiais, acabamos de ver que o papel dos escritores adquire proporções muito amplas, ultrapassando o mero deleite estético. A literatura tem sido, ao lado da música, o dedo que aponta os descompassos da descolonização e da má governança, o instrumento que desmascara e questiona, que destrói e reconstrói. Os autores aqui referidos, entre outros, marcam a conjuntura literária da Guiné-Bissau dos anos 1990 em diante com o selo do empenho de anular, pela representação textual de variados matizes, diferentes experiências de exclusão.

O espaço textual guineense revela-se marcado pelo exercício de uma "estratégia de descentramento", usando a expressão de Jacques Derrida, a partir da qual se desloca, expulsa do seu lugar, a cultura européia, que não é mais a única cultura de referência. A fala enunciadora, mediando o resgate do que havia ficado marginalizado, libera outras formas de dizer o mundo, articulando o saber local recém-descolonizado, inserindo-o no contexto da nascente nacionalidade, fazendo emergir fontes simbólicas e afetivas que plasmam a identidade cultural (BHABHA, 1998: 199) do recém-fundado Estado da Guiné-Bissau.

\section{Referências Bibliográficas}

APPIAH, Kwame Anthony. Na casa de men pai. A África na filosofia da cultura. Rio de Janeiro: Contraponto, 1997.

AUGEL, Moema Parente (Coord.). Kebur. Barkafon di poesia na kriol. Bissau: Instituto Nacional de Estudos e Pesquisa (INEP), 1996. (Série literária, Colecção Kebur, n. 1). - A nova literatura da Guiné-Bissau. Bissau: Instituto Nacional de Estudos e Pesquisa (INEP), 1998. (Série literária, Colecção Kebur, n. 8).

O desafio do escombro. A literatura guineense e a narração da nação. 2005. (Tese de Doutorado) - Faculdade de Letras, Universidade Federal do Rio de Janeiro, Rio de Janeiro, 2005. 
AURIGEMMA, Pascoal D'Artagnan. Djarama e outros poemas. Bissau: Instituto Nacional de Estudos e Pesquisa (INEP), 1996. (Série literária, Colecção Kebur, v. 5). Org., nota editorial e notas de Moema Parente Augel.

BARROS, Filinto de. Kikia matcho. Bissau: Centro Cultural Português da Guiné-Bissau, 1997.

BHABHA, Homi K. O local da cultura. Belo Horizonte: Ed. UFMG, 1998.

BOURDIEU, Pierre. A miséria do mundo. Petrópolis: Vozes, 1997.

CASTELLS, Manuel. O poder da identidade. São Paulo: Paz e Terra, 2002. (A era da informação: economia, sociedade e cultura, v. II).

FANON, Frantz. Peau noire, masques blancs. Paris: Seuil, 1952.

. Les damnés de la terre. Paris: Maspéro, 1961.

FERNANDES, Raul Mendes. Partido único e poderes tradicionais. Soronda. Revista de Estudos Guineenses. Bissau: INEP, v. 16, p. 39-50, 1993.

GEERTZ, Clifford. O saber local. 4. ed. Petrópolis: Vozes, 2001.

HALL, Stuart. A identidade cultural na pós-modernidade. 4. ed. Rio de Janeiro: DP\&A, 2000.

HARDT, Michael; NEGRI, Antonio. Império. Rio de Janeiro: Record, 2005.

LARANJEIRA, José Luís Pires. Literaturas africanas de expressão portuguesa. Lisboa: Universidade Aberta, 1995.

MARTINS, José de Souza. Exclusão social e a nova desigualdade. São Paulo: Paulus, 1997.

MEMMI, Albert. Portrait du colonisé suivi de portrait du colonisateur. Paris: L'Etincelle, 1966.

MONTENEGRO, Teresa. Uma primeira interrogação em crioulo à cultura popular oral. Africa. Literatura, arte e cultura. Lisboa, n. 6, ano II, p. 3-13, out./dez. 1979.

MONTENEGRO, Teresa; MORAIS, Carlos de (Org.). Uori. Storias de lama e philosophia. Bissau: Ku Si Mon, 1995.

N'DA, PAUL. Les intellectuels et le pouvoir en Afrique noire. Paris: L'Harmattan, 1987.

ORLANDI, Eni Puccinelli. As formas do silêncio. No movimento dos sentidos. Campinas: Unicamp, 1997.

ORTEGA, Julio. Crítica de la identidad. La pregunta por el Perú en su literatura. México: FCE, 1988.

PADILHA, Laura Cavalcante. Entre voz e letra. O lugar da ancestralidade na ficção angolana do século XX. Niterói: EDUFF, 1995.

- Novos pactos, outras fições: ensaios sobre literaturas afro-luso-brasileiras. Porto Alegre: EDIPUCRS, 2002.

SAID, Edward. Orientalismo. O Oriente como invenção do Ocidente. São Paulo: Companhia das Letras, 1990. . Cultura e imperialismo. São Paulo: Companhia das Letras, 1999.

SANTIAGO, Silviano. Uma literatura nos trópicos. Ensaios sobre dependência cultural. São Paulo: Perspectiva, 1978. 
SECCO, Carmen Lucia Tindó Ribeiro (Org). A magia das letras africanas. Ensaios escolhidos sobre as literaturas de Angola e Moçambique e alguns diálogos. Rio de Janeiro: ABE Graf, 2003.

SEMEDO, Odete da Costa. Entre o ser e o amar. Bissau: Instituto Nacional de Estudos e Pesquisa (INEP), 1996. (Série literária, Colecção Kebur, v. 3). Sonéá. Histórias e passadas que ouvi contar I. Bissau: Instituto Nacional de Estudos e Pesquisa, 2000a.

Djênia. Histórias e passadas que ouvi contar II. Bissau: Instituto Nacional de Estudos e Pesquisa, 2000b.

Histórias e passadas que ouvi contar. 2. ed. Viana do Castelo: Câmara Municipal, 2003a (Cadernos da Lusofonia n. 5). . No fundo do canto. Viana do Castelo: Câmara Municipal, 2003b.

SIGÁ, Félix. Arqueólogo da calçada. Bissau: Instituto Nacional de Estudos e Pesquisa (INEP), 1996. (Série literária, Colecção Kebur, v. 4).

SILA, Abdulai. Eterna paixão. Bissau: Ku Si Mon, 1994. - A última tragédia. Bissau: Ku Si Mon, 1995. . Mistida. Bissau: Ku Si Mon, 1997. Mistida (Trilogia). Praia-Mindelo (Cabo Verde): Centro Cultural Português, 2002.

. A última tragédia. Rio de Janeiro: Pallas, 2006.

TCHEKA, Tony [António Soares Lopes Jr.]. Noites de insónia na terra adormecida. Bissau: Instituto Nacional de Estudos e Pesquisa (INEP), 1996. (Colecção Kebur, v. 2). XIBERRAS, Martine. Les théories de l'exclusion. Paris: Meridiens-Klincksieck, 1993. 